\title{
Leucocyte profile and offspring production of guinea pig (Cavia cobaya) given Anredera cordifolia leaf extract
}

\author{
D. Wijayanti ${ }^{1{ }^{1 *}, \text { E. T. Setiatin }}{ }^{2}$ and E. Kurnianto ${ }^{2}$ \\ ${ }^{1}$ Department of Animal Science, Faculty of Agriculture, Perjuangan University of Tasikmalaya, \\ Jl Pembela Tanah Air 177, Kahuripan, Tasikmalaya 46115, West Java - Indonesia \\ ${ }^{2}$ Department of Animal Science, Faculty of Animal and Agricultural Sciences, \\ Diponegoro University, Tembalang Campus, Semarang 50275 Central Java - Indonesia \\ *CorrespondingE-mail : wijayantidwi12@gmail.com
}

Received September 30, 2017; Accepted January 09, 2018

\begin{abstract}
ABSTRAK
Tujuan penelitian ini adalah mengetahui profil leukosit dan jumlah anak dari marmut (Cavia cobaya) akibat pemberian ekstrak daun binahong (Anredera cordifolia). Materi yang digunakan adalah marmut betina masing-masing berjumlah 16 ekor dengan bobot badan $425 \mathrm{~g}$. Ekstrak daun binahong dengan dosis $0,10,50$ dan $90 \mathrm{mg}$, masing-masing ditetapkan sebagai T0, T1, T2 dan T3. Pemberian dilakukan secara oral, dari 0 hari prepartum sampai 10 hari postpartum. Pengambilan darah dilakukan 10 hari prepartum, pasca beranak, 10 hari postpartum, dan juga dilakukan pengamatan jumlah kelahiran dan kematian fetus pasca beranak. Data dianalisis menggunakan analisis ragam dilanjut analisis beda ratarata dengan Duncan Multiple Range Test untuk tampilan leukosit dan Chi-Square untuk produksi anak yang diberi ekstrak daun $A$. cordifolia dengan kontrol. Hasil menunjukkan bahwa kelompok perlakuan 10 hari prepartum (control) tidak berbeda nyata, kelompok perlakuan postpartum pada monosit total terjadi kenaikan tertinggi pada level $50 \mathrm{mg}$ /ekor dibandingkan dengan level 0, 10, dan $90 \mathrm{mg} / \mathrm{ekor}$. Kelompok perlakuan 10 hari postpartum pada leukosit total dan monosit total terjadi kenaikan tertinggi pada level 50 dan $90 \mathrm{mg} /$ ekor dibandingkan $10 \mathrm{mg} / \mathrm{ekor}$. Limfosit total terjadi kenaikan tertinggi pada level $90 \mathrm{mg} /$ ekor dibandingkan dengan level 10 dan $50 \mathrm{mg} / \mathrm{ekor}$. Neutrofil total kenaikan tertinggi pada level $50 \mathrm{mg}$ /ekor dibandingkan dengan level 0 dan $10 \mathrm{mg} /$ ekor. Pemberian ekstrak daun A. cordifolia dapat menaikan jumlah anak yang dilahirkan $(\mathrm{P}<0,05 ; \chi 2=9,267)$ dan dapat menurunkan jumlah anak yang mati $\left(\mathrm{P}<0,05 ; \chi^{2}=6,4\right)$. Kesimpulannya adalah pemberian ekstrak daun $A$. cordifolia $50 \mathrm{mg} / \mathrm{ekor}$ dapat meningkatkan profil leukosit dan produksi keturunan.
\end{abstract}

Kata kunci: Anredera cordifolia, total leukosit, differensial leukosit, Cavia cobaya, produksi keturunan

\begin{abstract}
The objective of this study was to determine leucocyte and offspring production of guinea pig (Cavia cobaya) giving Anredera cordifolia leaf extract. Materials used were female 16 heads of guinea pig with body weight of $425 \mathrm{~g}$. The treatments were an extract of $A$. cordifolia leaf at doses of $0,10,50$ and $90 \mathrm{mg} /$ head, designated as T0, T1, T2 and T3, respectively. A. cordifolia leaf extract was administered orally from 10 days prepartum to 10 days postpartum. Blood was taken at 10 days prepartum and 10 days postpartum. Total birth of the offspring was observed. Data were analyzed by analysis of variance and if there was effect of treatment, then continued with Duncan multiple range test and Chi-Square test for fetal production between the given A. cordifolia leaf extract and control. The result showed that there was no significant difference for 10 days prepartum after addition of $A$.
\end{abstract}


cordifolia leaf extract treatment. The postpartum treated showed a total $50 \mathrm{mg} / \mathrm{head}$ level increaed for monocytes than that of level 0,10 and $90 \mathrm{mg} / \mathrm{head}$. Ten days postpartum treatment showed the total increase for leucocyte and monocytes total were 50 and $90 \mathrm{mg} / \mathrm{head}$, respectively compared to 10 $\mathrm{mg} /$ head level. Total lymphocyte of $90 \mathrm{mg} / \mathrm{head}$ increased compared to level 10 and $50 \mathrm{mg} / \mathrm{head}$. The highest total neutrophil as found at level of $50 \mathrm{mg} / \mathrm{head}$ which increased compared to the level of 0 and $10 \mathrm{mg} / \mathrm{head}$. Provisioning A. cordifolia leaf extract at doses level of 50 and $90 \mathrm{mg} / \mathrm{head}$ could increase litter size $(\mathrm{P}<0.05 ; \chi 2=9.267)$ and decreased offspring mortality $(\mathrm{P}<0.05 ; \chi 2=6.4)$. In conclusion, by giving $50 \mathrm{mg} /$ head $A$. cordifolia leaf extract could increase leucocyte profile and offspring production of guinea pig.

Keywords :Anredera cordifolia, leucocyte total, leucocyte differential, Cavia cobaya, offspring production

\section{INTRODUCTION}

Decreasing in livestock productivity may lead to decrease animal reproduction. Abortion was one of the causes of decreasing reproduction. Nowdays, vitamins and antibodies were widely used for animals. However, the drugs leave a dangerous residue in the body of pregnant animals. Research conducted by Bahri et al. (2005) found many antibiotic residues and penicillin and tetracycline type hormones in beef and its liver. Herbs were plants containing active substances that were safe to be used. Binahong leaf (A. cordifolia) was one of the herbs that contain flavonoids, alkaloids, saponins and vitamin $C$ that could be used as an alternative for commercial antibiotics.

Flavonoids have the ability to recover damaged body cells. Flavonoids and terpenoids were isometric hydrocarbon compounds that help the process of organic synthesis and recovery of body cells (Astuti et al., 2011). The $A$. cordifolia leaf extract was containing an antioxidant that increases energy for stamina of the body. According to Vanhees et al. (2011), the work system of the flavonoid is by releasing hydrogen atoms from its hydroxyl groups.

Flavonoids were one of the active substances functioning as antifungal and antimicrobial. Microbial cells were damaged by the activity of the flavonoid. Damaged microbial cells could reduce the appearance of increasingly severe inflammation. According to the research of Clara et al. (2014), the flavonoid contained of 1-4 mg/ $\mathrm{mL}$ that derived from Monanthotaxis littoralis could inhibit the toxic microorganisms of mycotoxin producers. Plants contained by phenol and flavonoid compounds were more potent as antibacterial, antimicrobial, increase resistance to infection, accelerate healing and immunostimulant. Flavonoids could improve body health and reduce the risk of death. $A$. cordifolia also containing phytoestrogens could increase fertility in the females (Todaka, 2005). According to Beazley and Nurminskaya (2016), flavonoids also serve to keep the condition of the uterus when pregnant, so there was no abortion resulting in death on the offspring.

The purpose of this study was to determine leucocyte and fetal production of guinea pig (C.cobaya) by giving A. cordifolia leaf extract. Provisioning of $A$. cordifolia leaf extract was expected to increase endurance through animal experimental of C. cobaya during postpartum and on offspring production.

\section{MATERIALS AND METHODS}

Materials used were 16 female of C. cobaya with body weight $425 \mathrm{~g}$.

Determination of Total Flavonoid and $A$. cordifolia Leaf Extraction Preparation. The total of flavonoid content was determined by visible spectrophotometry as described by Wijayanti et al. (2017). Fresh leaves of $A$. cordifolia weighed $500 \mathrm{~g}$ then finely ground to maceration with ethanol $(1: 10)$ at room temperature for 5 days (Wijayanti et al., 2017). After maceration, filtration was done to obtain the filtrate. The filtrate was evaporated with a temperature of $70^{\circ} \mathrm{C}$ and produced a viscous extract. The extract was stored in the refrigerator (Djamil et al., 2012).

Experimental Procedure. The dose of $A$. cordifolia leaf extract was administrated based on animal weight body by converting human weight to C. cobaya (Kusumawati, 2004). Completely Randomized Design was used in this study with 4 treatments and 4 replications for leucocyte profile and Chi-Square test for offspring production. The 
doses of A. cordifolia leaf extract administered was $0,10,50$ and $90 \mathrm{mg} /$ head, designated as $\mathrm{T} 0$, $\mathrm{T} 1, \mathrm{~T} 2$ and $\mathrm{T} 3$ respectively. A. cordifolia leaf extract was diluted with $0.5 \mathrm{~mL}$ of aquadest for each provisioning. A. cordifolia leaf extract was administered orally from 10 days of prepartum to 10 days postpartum.

Blood Collection. Blood collection was done three times, i.e. firstly at before giving $A$. cordifolia leaf extract, secondly at 10 day prepartum and thirdly at 10 days postpartum according to Wijayanti et al. (2016).

Determination of Total Leucocytes, Leucocyte Differential and Examination of Blood Smear. Determination of total leucocytes was done according to Astuti et al. (2011) and smear preparation for leucocyte differential according to Irianti and Ardinata (2008). The cells was counted at least 100 cells and calculated as percentage of leucocyte types (neutrophils, eosinophils, lymphocytes and monocytes).

Litter size and Offspring Mortality. Data of litter size and offspring mortality were taken at postpartum by counting the litter size, average of offspring per female, offspring mortality and percentage of the offspring mortality on $C$. cobaya postpartum per female.

\section{Data Analysis}

Data were analysed by analysis of variance and if there was an effect of treatment, then continued to Duncan Multiple Range Test for leucocyte at $5 \%$ significances. Chi-Square test was performed for statistical analysis of offspring production (steel and Torrie, 1995).

\section{RESULT AND DISCUSSION}

\section{Total Leucocyte and Differential Leucocyte 10 Days Prepartum of Cavia cobaya}

Based on Table 1, total leucocyte and differential leucocyte was not significantly different $(\mathrm{P}>0.05)$. The $C$. cobaya condition was indicated in normal condition before being given A. cordifolia leaf extract. The normal total leucocyte, lymphocytes, monocytes, neutrophils, and eosinophil in guinea pigs ranged from 6.0$17.0 \times 10^{3} / \mathrm{m}^{3}, 2.4-13.6 \times 10^{3} / \mathrm{m}^{3}, 0.06-2.04 \times$ $10^{3} / \mathrm{m}^{3}, 1.2-9.25 \times 10^{3} / \mathrm{m}^{3}$ and $0.018-0.6810^{3} / \mathrm{m}^{3}$ (Smith and Mangkoewidjojo, 1988).
Total Leucocyte and Differential Leucocyte Postpartum of Cavia cobaya

Table 2 shows that total leucocyte, lymphocytes, neutrophils, and eosinophil total was no significantly different. Monocytes total was significantly different $(\mathrm{P}<0.05)$. A. cordifolia leaf extract in doses level of $50 \mathrm{mg} /$ head could increase total monocyte comparing to level of 0 , 10 and $90 \mathrm{mg} / \mathrm{head}$. Monocyte was increased due to a process of macrophage phagocytosis from inflammation postpartum in $C$. cobaya postpartum. Total monocytes in blood was showed as an indicator ability of $C$. cobaya to destroy microorganisms. Flavonoids in $A$. cordifolia have an important role to stimulate monocytes, macrophages, and other cells in the inflammatory and proliferative stages healing so that monocyte production was doubled (Sukrama et al., 2017; Sumartiningsih, 2011).

The flavonoids content in A. cordifolia leaf extract could increase total monocyte $C$. cobaya postpartum. Monocytes increased because flavonoids activate lymph nodes to increase monocyte production. Flavonoids have water soluble properties and serve as antimicrobials and immunostimulants (Astuti, 2016; Hu et al., 2016). Monocyte stimulates the body immunity so that cells do better. Immune levels increased when helped postpartum the healing process of uterine wounds, the body's cells would be more active to work and stay healthy when attacked by viruses, bacteria and microbes. The process of phagocytosis would be very active when total monocytes increases. According to Sukandar et al. (2016), monocytes increased because of the influence of flavonoids that work against lymphokines produced by $\mathrm{T}$ cells that would

Table 1. The Average of Total Leucocyte and Differential Leucocyte 10 Days Prepartum of Guinea Pig (C. cobaya)

\begin{tabular}{lc}
\hline \multicolumn{1}{c}{ Parameters } & Total \\
\hline Total Leucocyte $\left(\mathrm{x} 10^{3} / \mathrm{mm}^{3}\right)$ & $11.11 \pm 1.77$ \\
Lymphocytes $\left(\mathrm{x} 10^{3} / \mathrm{mm}^{3}\right)$ & $7.11 \pm 1.40$ \\
Monocytes $\left(\times 10^{3} / \mathrm{mm}^{3}\right)$ & $0.84 \pm 0.42$ \\
Neutrophils $\left(\times 10^{3} / \mathrm{mm}^{3}\right)$ & $2.89 \pm 0.78$ \\
Eosinophils $\left(\times 10^{3} / \mathrm{mm}^{3}\right)$ & $0.27 \pm 0.19$ \\
\hline
\end{tabular}


Table 2. The Average of Total Leucocyte and Differential Leucocyte Postpartum of Guinea Pig ( $C$. cobaya)

\begin{tabular}{lcccc}
\hline \multirow{2}{*}{ Parameters } & \multicolumn{4}{c}{ Doses of A. cordifolia Leaf Extract (mg/head) } \\
\cline { 2 - 5 } & 0 & 10 & 50 & 90 \\
\hline Total Leucocyte $\left(\mathrm{x} 10^{3} / \mathrm{mm}^{3}\right)$ & $7.98 \pm 4.70$ & $7.85 \pm 2.99$ & $10.77 \pm 1.42$ & $8.58 \pm 2.99$ \\
Lymphocytes $\left(\mathrm{x} 10^{3} / \mathrm{mm}^{3}\right)$ & $5.10 \pm 3.61$ & $4.93 \pm 1.59$ & $5.68 \pm 0.15$ & $4.87 \pm 1.91$ \\
Monocytes $\left(\mathrm{x} 10^{3} / \mathrm{mm}^{3}\right)$ & $0.48 \pm 0.37^{\mathrm{b}}$ & $0.63 \pm 0.28^{\mathrm{b}}$ & $1.25 \pm 0.21^{\mathrm{a}}$ & $0.72 \pm 0.38^{\mathrm{b}}$ \\
Neutrophils $\left(\mathrm{x} 10^{3} / \mathrm{mm}^{3}\right)$ & $2.18 \pm 1.21$ & $2.08 \pm 1.26$ & $3.29 \pm 0.99$ & $2.79 \pm 1.33$ \\
Eosinophils $\left(\mathrm{x} 10^{3} / \mathrm{mm}^{3}\right)$ & $0.21 \pm 0.19$ & $0.20 \pm 0.16$ & $0.08 \pm 0.01$ & $0.19 \pm 0.13$ \\
\hline
\end{tabular}

Different superscript in the same row indicates significantly different $(\mathrm{P}<0.05)$

stimulate phagocyte cells to respond to phagocytosis.

\section{Total Leucocyte and Differential Leucocyte 10 Days Postpartum of Cavia cobaya}

Total leucocyte and monocyte at 10 days postpartum treatment (Table 3) with $50 \mathrm{mg} /$ head of $A$. cordifolia leaf extract showed significant difference $(\mathrm{P}<0.05)$ with 0 and $10 \mathrm{mg} /$ head. Level of $50 \mathrm{mg} /$ head was not significantly different from levels of $90 \mathrm{mg} / \mathrm{head}$. Treatment of 10 days postpartum C. cobaya was a period of wound healing in the womb and an increase in total of leucocytes and monocytes. The total leucocyte would become an infected wound defence agent. Vinothapooshan et al. (2010) showed that leucocytes were the active unit of the body's defence system by providing rapid and robust defence against every infectious agent. The antioxidant compounds of $A$. cordifolia extract could minimize free radical attack on blood cells and the process of blood cell formation could increase so that leucocytes could be maintained or even increased (within normal limits) when the condition of the body was attacked by disease (Kumar and Pandey, 2013; Paju et al., 2013). Total saponin from $A$. cordifolia leaf extract would increase the number of monocytes $C$. Cobaya. The saponin of content in A. cordifolia leaf extract as antimicrobial in accelerating the process of proliferation in wound healing. According to Astuti et al. (2011) that saponins could increase the number of macrophages as monocyte phagocytes in order to secrete growth factors that could attract many fibroblasts and synthesize collagen.

A. cordifolia leaf extract was given $90 \mathrm{mg} /$ head level was significantly different of lymphocytes total $(\mathrm{P}<0.05)$ with levels of 10 and $50 \mathrm{mg} /$ head (Table 3). The lymphocyte was the highly increased at the level of $90 \mathrm{mg} / \mathrm{head}$ proved that the process of wound healing and endurance increases in attacking the stronger bacteria. Neutrophils total (Table 3 ) at $50 \mathrm{mg} / \mathrm{head}$ level was significantly different $(\mathrm{P}<0.05)$ with 0 and $10 \mathrm{mg} /$ head, but not significantly different with $90 \mathrm{mg} /$ head. The flavonoids of content in A. cordifolia leaf extract would increase the neutrophils total as infectious agent attacks. Sukmayadi et al. (2014) and Harikrishnan et al. (2010) stated that the main function of neutrophil cells was as bacterial cell phagocytosis, so that if swelling occurs in the limbs a large neutrophil total cells would be released. Chuang et al. (2007) indicates that neutrophils in the blood would increase in the event of infection and act as the first in the body and recovery of body cells and enhance immunoreactivity.

\section{Litter Size}

Provisioning A. cordifolia leaf extract at dose level of 10,50 and $90 \mathrm{mg} / \mathrm{head}$ extract significantly different on litter size $(\mathrm{P}<0.05)$ with value $\chi^{2}=9.267$ with $0 \mathrm{mg} /$ head (Table 4). This suggests that administration of $A$. cordifolia leaf extract could increase the total of litter size. The flavonoids or phytoestrogens of content helping the body's defence process with a rise in total leucocytes postpartum there by increasing the ability of the offspring to survive. Accumulating 
Table 3. The Average of Total Leucocyte and Differential Leucocyte 10 Days Postpartum of Guinea Pig (C. cobaya)

\begin{tabular}{lcccc}
\hline \multirow{2}{*}{ Parameters } & \multicolumn{4}{c}{ Doses of $A$. cordifolia Leaf Extract $(\mathrm{mg} / \mathrm{head})$} \\
\cline { 2 - 5 } & 0 & 10 & 50 & 90 \\
\hline Total Leucocytes $\left(\times 10^{3} / \mathrm{mm}^{3}\right)$ & $6.64 \pm 2.31^{\mathrm{ab}}$ & $4.30 \pm 0.97^{\mathrm{b}}$ & $9.51 \pm 0.40^{\mathrm{a}}$ & $8.95 \pm 2.60^{\mathrm{a}}$ \\
Lymphocytes $\left(\mathrm{x} 10^{3} / \mathrm{mm}^{3}\right)$ & $3.95 \pm 1.34^{\mathrm{ab}}$ & $2.57 \pm 0.57^{\mathrm{b}}$ & $2.44 \pm 0.92^{\mathrm{b}}$ & $5.33 \pm 1.51^{\mathrm{a}}$ \\
Monocytes $\left(\mathrm{x} 10^{3} / \mathrm{mm}^{3}\right)$ & $0.50 \pm 0.28^{\mathrm{ab}}$ & $0.25 \pm 0.06^{\mathrm{b}}$ & $0.72 \pm 0.07^{\mathrm{a}}$ & $0.81 \pm 0.26^{\mathrm{a}}$ \\
Neutrophils $\left(\mathrm{x} 10^{3} / \mathrm{mm}^{3}\right)$ & $1.99 \pm 0.80^{\mathrm{b}}$ & $1.38 \pm 0.44^{\mathrm{b}}$ & $3.54 \pm 0.53^{\mathrm{a}}$ & $2.66 \pm 1.38^{\mathrm{ab}}$ \\
Eosinophils $\left(\mathrm{x} 10^{3} / \mathrm{mm}^{3}\right)$ & $0.15 \pm 0.14$ & $0.10 \pm 0.05$ & $0.14 \pm 0.04$ & $0.14 \pm 0.10$ \\
\hline
\end{tabular}

Different superscript in the same row shows significantly different $(\mathrm{P}<0.05)$

Table 4. The Litter Size, Average of Offspring Per Female, Offspring Mortality and Percentage of the Offspring Mortality on Guinea Pig (Cavia cobaya) Postpartum

\begin{tabular}{ccccc}
\hline $\begin{array}{c}\text { Giving } \text { A. cordifolia } \\
\text { Leaf Extract (mg) }\end{array}$ & $\begin{array}{c}\text { Litter size } \\
\text { (head) }\end{array}$ & $\begin{array}{c}\text { Average of offspring } \\
\text { Per Female (head) }\end{array}$ & $\begin{array}{c}\text { Offspring } \\
\text { Mortality (head) }\end{array}$ & $\begin{array}{c}\text { Percentage of the } \\
\text { Offspring Mortality }\end{array}$ \\
\hline 0 & 4 & 1.00 & 1 & 25 \\
10 & 6 & 1.50 & 1 & 16.67 \\
50 & 4 & 1.00 & 2 & 50 \\
90 & 11 & 2.75 & 3 & 27.27 \\
\hline
\end{tabular}

evidence that dietary bioflavonoids were beneficial for health and longevity (Beazley and Nurminskaya, 2016). Provisioning phytoestrogens during pregnancy could actually increase the immunity of the fetus in the uterus so that there was no early birth. This was in accordance with the opinion of Todaka (2005) that provision phytoestrogens to the female during pregnancy would transmit phytoestrogens from the female to the offspring. According to Tshikalange et al. (2005), the process transfer of phytoestrogens from female to offspring through the placenta was influenced by blood pressure, placental type, molecular size, $\mathrm{pH}$, flow rate (blood flow rate).

\section{Offspring Mortality}

Provisioning of $A$. cordifolia leaf extract was significantly different with no treatment $(\mathrm{P}<0.05)$ with value $\chi^{2}=6.400$. The higher provisioning of A. cordifolia leaf extract could decrease offspring mortality (Table 4). The ability of the decrease offspring mortality happens because $A$. cordifolia leaf extract in the form of flavonoids and phytoestrogens stimulates the female body to always maintain the condition of the body during the pregnancy. Flavonoids have antioxidant functions that inhibit the presence of free radicals that could interfere with the development of children while they still in the womb. The ability of children to survive the free radical attacks then the offspring mortality rate during the birth process was getting less. Free radical was one of the causes of abortion. Flavonoids as antioxidants overcome the emergence of free radicals that damage fetal growth cells during pregnancy (Vanhees et al., 2011). Free radicals could be able to make offspring with birth defects or stillbirth. The A. cordifolia leaf extract content has a role in strengthening the uterine wall and maintaining the hormone progesterone so as not to experience 
abortion. This is in accordance with the research of Fan et al. (2015) using cows fed $200 \mathrm{mc}$ and $300 \mathrm{mc}$ of quercetin per $\mathrm{kg}$ diet showed higher rates of living and healthy offspring than that of controls.

\section{CONCLUSION}

Provisioning A. cordifolia leaf extract at 50 $\mathrm{mg} /$ head could increase leucocyte profile and offspring production of guinea pig (C. cobaya).

\section{REFERENCES}

Astuti, S.M., M.A. Sakinah, R. Andayani and A. Risch. 2011. Determination of saponin compound from Anredera cordifolia (Ten) Steenis plant (Binahong) to potential treatment for several diseases. J. Agric. Sci. 3(4):224-32.

Astuti, P. 2016. The ability of anti-inflammatory jatropha curcas leaf extract at cox-2 expression on monocytes were exposed lps. Proceeding ICMHS. P. 154-157.

Beazley, K.E. and M. Nurminskaya. 2016. Effects of dietary quercetin on female fertility in mice: implication of transglutaminase 2 . Reprod. Fertil. Dev. 28(7):974-981.

Bahri, S., E. Mabulan and A. Kusumaningsih. 2005. Proses praproduksi sebagai faktor penting dalam menghasilkan produk ternak yang aman untuk manusia. Jurnal Litbang Pertanian. 24(1): 27-35. (In Indonesia).

Chuang, M.T., Yin-Shio Lin and Wen-Chi Hau. 2007. Ancordin, the major rhizome protein of madeira-vine, with trypsin inhibitory and stimulatory activities in nitric oxide productions. Peptides. 28:1311-1316.

Clara, C., J.C. Matasyoh, I.N. Wagara, J. Nakavum. 2014. Antifungal activity of flavonoids isolated from Monanthotaxis littoralis against mycotoxigenic fungi from maize. Am. J. Chem and Application. 1(4): 54-60.

Djamil, R., P.S. Wahyudi, S. Wahono and Hanafi. 2012. Antioxidant activity of flavonoid from Anredera cordifolia (ten) steenis leaves. J. Pharm. 3(9):241-243.

Fan, Z., Y. Xiao, Y. Chen, X.Wu, G. Zhang, Q.Wang and C. Xie. 2015. Effects of catechins on litter size, reproductive performance and antioxidative status in gestating sows. Anim.Nut. 1:271-275.

Harikrishnan, R., C. Balasundaramb and M.S.
Heo. 2010. Effect of probiotics enriched diet on paralichthys olivaceus infected with lymphocystis disease virus (LCDV). Fish Shellfish Immunol. 29:868-874.

Hu, Q.L., L.J. Zhang, Y.N. Li, Y.J. Ding, F.L. Li. Purification and antifatigue activity of flavonoids from corn silk. Int. J. Phys. Sci. 5(4):321-6.

Irianti, E. and Ardinata. 2008. Pengaruh aktivitas fisik sedang terhadap hitung lekosit dan hitung jenis lekosit pada orang tidak terlatih. Majalah Kedokteran Nusantara. 41(4): 259267. (In Indonesian).

Kumar, S. and A.K, Pandey. 2013. Chemistry and biological activities of flavonoids: an overview. Sci. World J. 10:1-17.

Kusumawati, D. 2004. Bersahabat dengan Hewan Coba.Gadjah Mada University press, Yogyakarta. (In Indonesian).

Paju, N., V.Y.Y. Paulina and N. Kojong. 2013. Uji efektivitas salep ekstrak daun binahong (Anredera cordifolia (Ten.) Steenis) pada kelinci (Oryctolagus cuniculus) yang terinfeksi bakteri Staphylococcus aureus. J. Ilmiah Farmasi. 2(1):51-61. (In Indonesian).

Steel, R.G.D., J.H. Torrie and D.A. Dickey. 1997. Principles and Procedures of Statistics A Biometrical Approach. 3rd Edition, McGraw Hill Co., Inc., New York.

Smith, J.B. and S. Mangkoewidjojo. 1988. Pemeliharaan, Pembiakan dan Penggunaan Hewan Percobaan di Daerah Tropis. Penerbit Universitas Indonesia, Jakarta. (In Indonesian).

Sukandar, E.Y., I. Fidrianny, T. Nofianti and D. Safitri. 2016. Subchronic toxicity study of corn silk (Zea mays l.) In combination with binahong (Anredera cordifolia (ten.)) Steenis leaves on wistar rats. Asian. J. Pharm. Clin. Res. 9(1):292-296.

Sukmayadi, A.E., S.A. Sumuwi and M.B. Intan. 2014. Aktivitas imunomodulator ekstrak etanol daun tempuyung (Sonchus arvensis Linn.) terhadap peningkatan il-2 pada tikus putih jantan galur wistar. Indonesian J. Pharm. Sci. Technol. 1(2):42-51. (In Indonesian).

Sukrama, D.M., D.M. Wihandani and A.P. Manuaba. 2017. Topical binahong (Anredera cordifolia) leaf extract increases interleukin-6 and vegf (vascular endothelial growth factor) during burn wound healing in wistar rats infected with pseudomonas aeruginosa. Biol. Med. 9(1):1-6. 
Sumartiningsih, S. 2011. The effect of binahong to hematoma.World Academy Sci. Engineer. Technol. 78: 743-745.

Todaka, E. 2005. Fetal exposure to phytoestrogens - the difference in phytoestrogen status between mother and fetus. Environmental Res. 99(2):195-203.

Tshikalange, T. E., J. J. M. Meyer and A. A. Husein. 2005. Antimicrobial activity, toxicity and the isolation of a bioactive compound from plants used to treat sexually transmitted diseases. J. Ethnopharmacology. 96:515-519.

Vanhees, K., L. de Bock, R. W. Godschalk, F. J. van Schooten and S. B. van W. van D. Khosrovani. 2011. Prenatal Exposure to Flavonoids: Implication for Cancer Risk. Toxicol. Sci. 120(1):59-67.

Vinothapooshan, G. and K. Sundar. 2010. Wound healing effect of various extracts of Adhatoda vasica. Int. J. Pharm. Biol. Sci. 1(53):0-6.

Wijayanti, D., E.T. Setiatin and E. Kurnianto. 2016. Efek ekstrak daun binahong (Anredera cordifolia (Ten) Steenis) terhadap profil darah merah pada marmut (Cavia cobaya). J. Sains Vet. 34(1):75-83. (In Indonesian).

Wijayanti, D., E.T. Setiatin and E. Kurnianto. 2017. Study on postpartum estrus of guinea pigs (Cavia cobaya) using Anredera cordifolia leaf extract. Vet. Word. 10(4): 375-379.

Yuziani, U. Harahap and Karsono. 2014. Evaluation of analgesic activities of ethanolic extract of Anredera cordifolia (Ten) Steenis leaf. Int. J. PharmTech. Res. 6(5): 1608-1610. 